\title{
The World of Design, a Designed World: the Relevance of Aesthetics for Everyday Life
}

\author{
Anna Calvera \\ University of Barcelona; GRACMON UB Research Unit \\ acalvera@ub. edu
}

\begin{abstract}
At present, the issue of the aestheticisation of capitalism, and the commercial and everyday world too, is taken for granted. It is a widely accepted approach to understand the $21^{\text {st }}$ century paradigm. However, the aestheticisation issue itself recurrently takes the blame for the present situation and so the field of aesthetics is assuming rather negative new meanings. Historically, this can be considered part of the legacy of recent postmodernism. It is true that aesthetics and a sort of aestheticism drive many consumerist behaviours across the world at present. Nonetheless, consumerism is just one social behaviour among many others in which the aesthetic faculty, the sense of beauty or ugliness, is at work. However, from design and the design culture points of view, aestheticisation may not necessarily carry evils; on the other hand, it could also be a consequence of a careful and ethical approach to the making of things while preserving their original values. Is it possible to develop an aesthetic discourse outside arts and fine arts? Is it possible to reflect upon all those humble, useful and pretty things that populate everyday life for so many people across the world? In fact, aesthetic worth is seldom recognised and rarely appreciated if objects are not identified as pieces of art. Whether meaning the human faculty able to enjoy beautiful and attractive things, or the discourse about the feeling of enjoyment gathered historically by humanities, aesthetics can have a wider scope,

much bigger than the small area that of Fine Arts deals with. An aesthetic dimension can and should be observed in every element that shapes daily life, whether commodities, appliances or tools that are noticed, touched and experienced through the senses, or places to live in and behave inside, breathing and enjoying a special atmosphere - this factor can be perfectly adapted to screens and their sensitive representation of the world inside; the aesthetic dimension extends to benefiting from services as well, with their ensuing individual appearance duly converted into visual signs $[[:-)=$ : (this is a picture: see Fig. 1!]. Surprisingly, all these common and widely shared features of human life are at present rarely acknowledged as factors of humanising and civilising processes. This text aims to reflect upon the humblest and most common side of aesthetic behaviour and choices, these aesthetic joys that are so important in managing everyday life, communicating with other people, providing personal wellbeing and guaranteeing quality of life for a wide social community. The reflection in this text reviews philosophical aesthetics and considers that aesthetic appreciation and enjoyment are everlasting human behaviours, a human competence that operates to build up the artificial world. Then, because aesthetic categories for dealing with ordinary, trivial and everyday life are not easy to define theoretically and have rarely been considered by philosophical aesthetics, the aim of
\end{abstract}

A Revista Estudos em Comunicação é financiada por Fundos FEDER através do Programa Operacional Factores de Competitividade - COMPETE e por Fundos Nacionais através da FCT - Fundação para a Ciência e a Tecnologia no âmbito do projeto Comunicação, Filosofia e Humanidades (LabCom.IFP) UID/CCI/00661/2013.

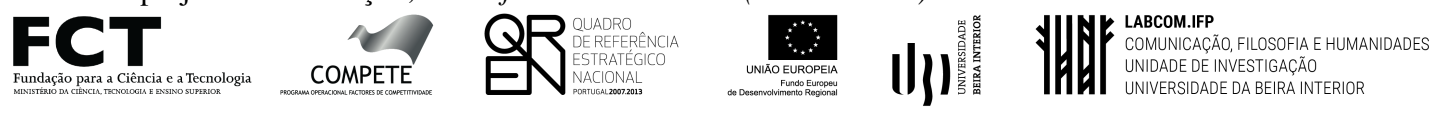


this chapter is also to show some positive aesthetic

issues related to present everyday life as it is lived on both sides of the screen.

Keywords: design aesthetics; aestheticisation; prosaic; design factor; everyday life.

Figure 1. A visual sign marking the tone inspiring a written text that works as punctuation marks do

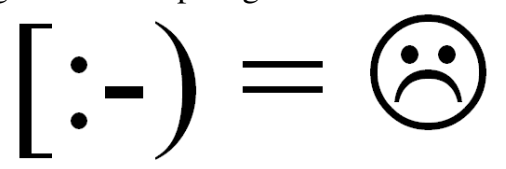

\section{An invitation received and a commission clearly proposed}

T AST summer, an invitation arrived to participate in a seminar dealing with the future of humanities and human beings, organised by the Research Unit of the University of Beira Interior (Covilhã, Portugal). Its intellectual background was clearly displayed in the event's programme: first, the arrival of digital humanities which brought new procedures to research into the field, requesting a new 'know how' and revealing renewed inquiry processes; secondly, the post-human, new-humanism and trans-humanism debates going on in many different disciplines in parallel; finally, the search of fitter means of approaching and understanding present times which hypothetically form a new historical era which we are only just reaching, given that we are also living in a transitional moment - incidentally, I actually think that the present transition will profoundly change the sort of world I know and was accustomed to.

In my case, the invitation suggested to me that I lecture about current aesthetic thinking, a sphere of philosophy which is evolving because it can help people - trade managers, marketing technicians and analysers of 3.0 new mass-culture included - to portray and understand present life's peculiarities and novelties. Specifically, the invitation read as follows: "O evento consiste em pensar as Humanidades hoje desde o ponto de vista do impacto tecnológico e de uma importância crescente conferida à estética, a partir de várias perspectivas (da Comunicação, da Filosofia e das Artes)" ["The event consists of thinking about humanities today regarding technology's impact and the growing importance assigned to aesthetics from several perspectives (communication, philosophy and the arts)"']. The challenge involved quickly became clear: I have spent many years researching similar and related topics, trying to apply philosophical aesthetic thinking to the understanding of design practice and culture, a modern and current phenomenon which is developing in constant dialogue with the arts. Design aesthetics' task can include the presentation of a professional practice and its results, the good works that professional designers physically produce, or the appraisal of the weight the aesthetic dimension actually has within design management and decision making throughout the designing processes. ${ }^{1}$ (A parenthesis to introduce a new premise:

1. CALVERA, Anna (2007), De lo bello de las cosas, Materiales para una estética del diseño, Barcelona: Gustavo Gili, e-book available. Its introduction was presented in English at the EAD Conference held in Izmir in 2008. 
at present, many scholars say that the action of designing is no longer an attribute of professional designers but instead a human faculty and skill shared by everybody, an element of the strategic way of thinking. This is one of the meanings of the word 'design' in English, the verb 'to design' that is usually spread by design managers at present; I am instead interested in the old meaning designating a professional industry, a discipline and a universe of goods and useful things made to live with -this is why professional designers rarely work doing things, they rather work making them whilst building up and giving form to the material and sensitive side of the artificial world. This is the sense of the Spanish word 'diseño', clearly distinguished from 'dibujo', and the Portuguese 'desenho', meaning drawing. The parenthesis ends here). Within this specific domain, I usually refer to a particular element of current products where design and aesthetics come together: the design factor, a concept I found used for the first time by design and communication managers. For that reason, I suggested the following topic to Professor João Carlos Correia, who was the event's coordinator: rethinking the aesthetic dimension in a broad sense and focusing on the everyday world, the nearby world existing outside the world of art, either fine or decorative. He answered quickly: "The relevance of aesthetics in everyday life and the aestheticisation of everyday life seems to be a very good choice". I was highly delighted to accept the challenge.

\section{Introducing the design factor: the aesthetic node in the nature of design and designed things}

Let us start at the end of the story. The design factor is an ingredient of designed things that designates a special way of being for several objects, just the well-designed ones, whether they are tools, gadgets, useful appliances, ornaments, graphics and visual signs, or places and spaces with a specific atmosphere too. They include any goods that can be found in our immediate and common environment: books printed, drawings, pieces of furniture, machines, screens and navigation menus or web sites... The design factor is an attribute, structurally a sort of adjective, that distinguishes and selects, from among this pile of things, objects, spaces and visual communications, which ones can seek to enter a specific and creative world of excellence, the world of designed things, or even, the world of design itself. ${ }^{2}$ It is difficult to define this factor, as so often happens with aesthetic categories. Aesthetic qualities are very easy to appreciate looking around and aesthetic categories are even more easy to apply when talking informally about things, people and landscapes around us, but it is also difficult to explain why something deserves to be qualified as belonging to a specific aesthetic category: and it is truly and even more difficult to justify a judgement that is as spontaneous and immediate as aesthetic judgement actually is.

Indeed, the design factor is not a style or a lifestyle, a system or a catalogue of canonical forms, a range of ornamental patterns or a repertoire of patterns and decorative motifs, nor is it a code of decorative guidelines or an aesthetic canon. Yet there are some objects that stand out for their design, just because their design is good. They thus have an appearance and performance that look 'designerly', which can be recognised as the expression of well-made design. This can

\footnotetext{
Concerning the design factor considered as an expression of the aesthetic dimension of designed products, see 'What is design? Design is...' in Pilar Vélez (ed.) (2014) From the world to the museum, Product Design Cultural Heritage, Barcelona, the Museum of Design of Barcelona \& ICUB, Barcelona City Council, pp. 181-2015.

2. Here I am using the word World in the sense defined by Nelson Goodman 1978, Ways of Worldmaking.
} 
also venture into an excess of design and, when that happens, although it is a 'designy' object, it is no longer a good design but a snobby or pretentious one instead. For that reason, the word 'design' becomes an axiological concept too: a judgement of value and worth which determines that intrinsic and extrinsic qualities are consistently related, something that is very significant for most common objects and tools. Although being selective in this way - it marks out several objects from their peers - the qualitative notion of goodness in design should not necessarily be elitist or exclusivist. To use a paradox, it can mean the quality of quality within designing practice. ${ }^{3}$

One of the best explanations I have ever heard about this evanescent factor came from a salesman at Barcelona's flea market. He is an antique dealer working with industrial tools and second hand goods as well, usually selling electric devices. In a doctoral research project devoted to reconstructing the biography of a very useful electrical appliance, the immersion hand blender, the man was inquired about how he knows which devices will sell well. He quickly answered that, for him, it was obvious, really easy to perceive. For that reason, his explanation can be accepted as a clear definition of what good design actually is, a feature beyond a historical style:

... I've had blenders that, because of their design, had a long 'hook' [metaphorically, attractiveness]. I did not choose them because they were well known, but because they themselves show it. Any object, if it has a design that strikes you, me, anyone... then it is good one. Always! It always happens like that. Not with the oldest ones, no! Because any industrial object, if it is very old, has a look that is nothing like the current appearance. Design developed an appearance: for example, in the case of typewriters, the form of a typewriter that we first think of is totally different from the first typewriters (...) And this usually happens with any object (... Hence) I see an object that is good and pleases me, and that's it. ${ }^{4}$

Another interesting attempt to define the design factor is provided by the manager Xènia Viladàs. She uses another expression to describe this qualitative attribute, the 'wow! factor', something very close to aesthetic appreciation and enjoyment:

A well-designed object has what is called the 'wow! factor': this is what stirs us and that, when we realise it, we make an exclamation of admiration that sums up our appreciation for both the aesthetics and the conceptual solutions at the same time. [Viladàs 2008: p.161]

Translating her assessment into graphic design theory terms, she is talking about a value called readability among typographers, something that complements legibility, which is a functional

3. I am arguing against all these such widely held thoughts that fear the democratisation of aesthetic values, activities, competences and whatever cultural manifestation, because it always inevitably brings about a banalisation of art and aesthetics. Trivialisation does not mean the same than banalisation because culturally speaking, it rarely turns into vulgarisation or a symbolic impoverishment of cultural sense. A good example of the idea I am trying to refute was provided by Chesterton a long time ago: "It is the pathos of many hackneyed things that they are intrinsically delicate and are only mechanically made dull." G.K. Chesterton (1929/2nd) Breve historia de Inglaterra, Barcelona, El Acantilado, 2005 [original English version of the book, available at: www.basilica.org/pages/ebooks/G.K.ChestertonA\%20Short\%20History\%20of\%20England.pdf

4. This is a transcription of the answer given by Mr. Víctor Gómez, merchant of vintage design products at Els Encants, the Barcelona flea market, to researcher Rosa Povedano (2005). 
attribute. Swiss modern design school preferred to call it communicability. It means the inviting tone some objects have while being quiet, calm and trouble-free; in other words, being as subtle as they are attractive and exciting: a difficult paradox, but an interesting challenge, at least for designers who love their job.

It is currently very common to talk about vital and emotional experiences to explain the sort of relationship users have with the objects and goods they possess or the places they use. Sensations, experiences or emotions, however, although forming the core of the design factor, are not enough to provoke the 'wow! factor' reaction spontaneously; in fact, things are a little bit more complex. Indeed, as ancient aesthetic philosophy easily discovered, emotions, sentiments and experiences belong to another domain far away from the realm of beauty, prettiness, and therefore plenty of steady pleasures and joys. On the other hand, striking emotions, strong feelings and troubling experiences all belong to the realm of the sublime. They become sublime only when they are truly worthy. But sublime experiences are quite often really ugly and rather unpleasant as far as art aesthetics and pathos are concerned. They may even address dangers and evils existing in life; in fact, the extraordinary side of common people's everyday lives can unfortunately be found in the worst aspects of politics such as war conditions in spite of their aestheticisation through epic narrative. Hence, imported through comparison with the aesthetic experience concept that philosophers have been developing for as long as philosophical aesthetics has existed, words such as emotions or experiences give a very grave and perhaps too pompous tone to discussions on design matters. It can also be confusing for people, who may forget all these humble pleasures and joyfulness sitting in everyday life.

Turning again to ordinary life and the realm of beautiful things, it could be interesting to reflect upon what the conceptual dimension of a product should be. Technically speaking, a design or product concept brings together various factors: a historical type, which is a mental idea familiar to everyone and socially well known - similar to the 'ideal types' once defined by Max Weber; several functions that connect one product with the customs and habits of people using it; some technical procedures; and then a discourse of consistency and coherence of the whole brought about by the act of designing itself. For that reason, the synthesis implicit in a design concept can be as important as its attractive appearance (or rather, popularly speaking, a pretty or handsome look) when discovering its main values as a cultural item. ${ }^{5}$ This makes design aesthetics more interesting theoretically. A design concept is a complex idea and for that reason it can acquire a deep meaning, becoming the expression of culturally relevant wisdom, as we will see later. On the other hand, complex but still humble and plain, everyday pleasures are a cultural expression too and so they can have cultural worth as well: whilst trivial, they are not necessarily banal or futile. A practical example: Roca is a Catalan company producing bathroom fittings and devices. Its production intends to improve people's time in the bathroom, as a very private and personal moment of everybody's day. Some years ago, at the Barcelona Roca Gallery, an exhibition was

5. Hannah Arendt once inquired about the relationship between aesthetics and politics in polis life. For her, discerning about political affaires is also a task performed by aesthetic taste (2014: p.64). For that reason, it is clear that aesthetic judgement could also apply to moral judgement. This is the sense of the Spanish word "cursi", related to a specific way of behaving, a mode of being and a formal style at the same time. In English, categories such as "nasty" or "shoddy" also fit into that genre of words. 
set up to display better ways of using water and it proposed the following slogan summarising the company's design philosophy:

\section{Life's little pleasures.}

It seems like we pay less and less attention to the little things in life, the simple, trivial, day-to-day things. But there are still many people who are able to get a great deal of enjoyment from what some may regard as 'insignificant'. There are happy people who can enjoy anything no matter how small. We don't have to overlook the small, modest pleasures that life can offer; happiness doesn't depend so much on wealth or material things, but rather on our eyes being able to appreciate the thousands of details that appear before us every single day [Introductory text, Roca Barcelona Gallery, winter 2013].

It is worth remembering now the contribution made by philosophers in the $18^{\text {th }}$ century to the understanding of humankind's aesthetic behaviours. Over two intense and transnational debates, one about luxury and commodities, the other on taste and the variety of tastes, British Empiricists and French Enlightenment thinkers (before Kant) were concerned with the beauty of useful things. They considered it an important outcome of the huge efforts made by humankind throughout history to improve their living conditions and it was therefore judged to be a discernible demonstration of human progress looking after wellbeing. For them, living comfortably required taking care and cultivating physical appearance as much as cultural training: people's cultural refinement can be seen easily "in the cure of their garden, their dressing with elegance and the delicacy of their house." All these issues are addressed today by mass magazines for women of different prices and have even given rise to many programmes devoted to these issues on the biggest international TV channels.

But beyond different canons of beauty spread by the mass media, does that mean that the act of taking care of things and oneself is not important because it is essentially trivial and common? It is true that throughout history the aesthetic care of houses and homes gradually became a housekeeping task and so, at that time, it became a female competence, an intellectual competence as underrated as so many other female tasks and tastes have often been since then. Focusing on sensory perception, appreciation and enjoyment, appealing to a world of sensations and pleasant feelings, 18th century philosophers were able to turn feeding and nutrition into gastronomy: to cultivate the pleasures of the palate, trying new food and thereby developing and refining their sense of taste. It is also worth remembering that the word used to designate the faculty of aesthetic judgment is the same one that designates the specific sense active whilst eating. It is the most immediate and elementary moment of appreciation, the true "I like".

[Further underlying hypotheses] Design is also an aesthetic practice but different to art and arty ways of thinking, speaking and performing (and behaving too)

There are several motivating hypotheses underlying the current notion of the design factor itself in the way design studies, design management and marketing theories generally use it (and as it is used here). The basic hypothesis inspiring this inquiry is the ubiquitous nature of the aesthetic dimension insomuch as it provides attributes and worth to all the perceptive shapes of the material world and sensible realities. It is the premise that bridges philosophical and design ways 
of thinking and dealing with common goods and visual communication messages. In fact, most philosophers recognise this aesthetic dimension as a given. Recently, French sociologists Lipovetsky $\&$ Serroy take for granted the anthropological nature of aestheticist decisions informing so many social behaviours at least since prehistoric times (2013: pp.15-31 "L'artialisation rituelle"). While acknowledging how deeply aesthetic needs and activities are rooted in ancient history, these authors at the same time recognise aesthetics as a central issue in today's postmodern and globalised societies. It must be supposed that aesthetics and taste have also been a factor in the wide acceptance of designed products around the world and so looks such as the Good Design, the Gute Form or the Bel Disegno became the visible guarantee of technological innovation and products' technical quality.

Some years earlier, on the threshold of the Western society of abundance, the philosopher Hannah Arendt also spoke about the inherent beauty of prosaic and ordinary things, even the most ordinary and commonplace ones. In that sense, she was following Heidegger's way of approaching useful things and tools, defining them as 'beings ready-to-hand' or 'things-at-hand.' Referring to Hannah Arendt is hence doubly interesting at a seminar about the human condition in a digitalised world such as the one organised by the University of Beira Interior in 2016. Indeed, Arendt analysed logical procedures and reflected on the sort of intelligence that early digital machines claimed as their own. She wrote that in 1958, almost sixty years ago. There is no doubt that she had an advanced position, foreseeing a little bit how artificial intelligence could evolve afterwards and influence human beings and humanities' discourse.

Arendt's quotation on useful objects is rather long. In her most famous book, The Human Condition, aesthetics, by singularising arts, is one of the factors that give stability to the artificial world where human beings live. It also supports the trusting relationship people have with tools and everyday equipment whilst using them: "things give to human artifice the stability without which it could never be a reliable home for men...". Above these stand works of art. They are what actually interest her but, as Heidegger thought in his time,${ }^{6}$ she also extends her reasoning to tools, goods, devices and appliances as counterparts of artworks to understand art's nature and way of being. Arendt also compares artworks to industrial machines: they are very representative of homo faber's work [pp. 38-39 Spanish text]. According to both Heidegger and Arendt, transfiguration is what makes the difference and turns artworks into something beyond their materiality as things: they transcend and enter the extraordinary world. Regarding design theory, what is interesting is the way in which she demonstrates the existence of the aesthetic dimension and its ubiquity across the physical world. Being embodied in whatever physically exists and is considered through the senses, aesthetic enjoyment is something actually inevitable: everyday things - goods, tools, communicative signs and graphics - are naturally pretty or ugly, elegant or corny, delicate or nasty in spite of their designers', marketing technicians' and manufacturers' intentions:

For although the durability of ordinary things is but a feeble reflection of the permanence of which the most worldly of all things, works of art, are capable, something of this quality - which to Plato was divine because it approaches immortality - is

6. I studied Heidegger to grasp how his thought applies design aesthetics in Anna Calvera: "El cosear de las cosas. Consideraciones rezagadas a partir de Martin Heidegger" in Calvera 2007: pp.101-123. 
inherent in every thing as a thing, and it is precisely this quality of the lack of it that shines forth in its shape and makes it beautiful or ugly. To be sure, an ordinary use object is not and should not be intended to be beautiful; yet whatever has a shape at all and is seen cannot help being either beautiful, ugly, or something in-between. Everything that is, must appear, and nothing can appear without a shape of its own: hence there is in fact no thing that does not in some way transcend its functional use, and its transcendence, its beauty or ugliness, is identical with appearing publicly and being seen. By the same token, namely, in its sheer worldly existence, everything also transcends the sphere of pure instrumentality once it is completed. The standard by which a thing's excellence is judged is never mere usefulness, as though an ugly table will fulfil (sic) the same function as a handsome one, but its adequacy or inadequacy to what it should look like, and this is, in Platonic language, nothing but its adequacy or inadequacy to the eidos or idea, the mental image, or rather the image seen by the inner eye, that preceded its coming into the world and survives its potential destruction. In other words, even use objects are judged not only according to the subjective needs of men but by the objective standards of the world where they will find their place, to last, to be seen, and to be used. [Arendt 2014: p.38-39; italics are in the original writing]

In another text in the same anthology quoted above, Arendt is even more explicit about the inevitability, or rather the inexorableness, of the aesthetic dimension of the artificial environment of human life, although barely arguing against instrumentalist reason in cultural and arts matters, whether functionalism or utilitarianism - two concepts that mean things that are completely different and refer to domains quite distant from each other. Arendt defines beauty from its everlasting trait, its imperishable nature:

...Beauty itself (...) belongs primarily to the sphere of production and is one of the criteria that makes it up, because all objects have a look and a way that is peculiar to its own status as objects. In this sense, beauty continues to function even as a criterion for useful objects, this is so not because the 'functional' objects can become beautiful, but quite the contrary, because all objects, including those of use, have life beyond its functionality. Functionality, on the other hand, it is not the aspect under which an object appears; that aspect corresponds to its shape and configuration. Functionality of things is the propriety under which objects disappear again once been used and consumed. To be able to assess an object only by its use value and not its appearance -to say if it's beautiful or ugly, or something in between-we must first shut our eyes. ${ }^{7}$

This special 'imperishable trait' that some products have, an aesthetic clue often compared to artistic qualities, becomes the design factor in a well-designed world. In the craft and handicrafts domains that produce commonplace things, the aesthetic clue is clearly an artistic value, a creation of genius; on the other hand, in the advanced craftily made current technologies that ICT is

7. Original text: “Cultura y política”, Merkur 12,1959. Quoted from Arendt 2014, Op. Cit., pp.58-59. 
spreading inside the screen, the aesthetic clue might adopt peculiarities far away from the artistic ones, falling aesthetically on the same side as designed things. My position is hence that everyday prettiness and beauty, although prosaic and trivial, even humble, futile and perhaps modest, are far more interesting and socially important than most philosophical aesthetics and cultural criticism are willing to accept. This genre of aesthetic thinking is therefore worth taking into account and so research can deal with the basis of aesthetic quality in the artificial environment where human life still takes place. Dealing with aesthetic quality and managing the varied qualities of beauty was design activity's original task when the design function operating within productive manufactures and factories became aware of the need to take care of aesthetics while producing goods and saw it as part of their social responsibilities; in Europe, this happened at the turn of 20th century. At that time, design was conceptualised as a practice that was as much aesthetic as it was instrumental, functional and technical. Its early mission was to facilitate and perform the dialogue between people and produce things whether launched on the market, displayed at shops or placed in a home or public space. That is why, a long time ago, design was understood as a procedure for domesticating technology together with technological innovation; this was covered in Deutches Werkbund's theorisation of design practice just before the First World War. A little later, Modern Design movements always sought a pleasant and polite beauty for the useful and common things they created. Seen as its own early inspiring utopia, modern and postmodern design heritages are hence the democratisation of aesthetic experiences and the reversal of all inherited aesthetic canons and social meanings. At present, because there is no longer a single, unique canon of reference for beauty, something which is often felt as a missing value, everyday aesthetics is an even more interesting issue than the obvious variety of tastes that people such as David Hume and Emmanuel Kant faced in the $18^{\text {th }}$ century, when modern times started to give rise to bourgeois and industrial societies. Nowadays, postmodernity is already out, but design is still considered a means of mediating between technological innovation and its users. An important task that design should exert is to ease the relationship between humans and machines through navigation tools and signs, improving interfaces and so, revealing the latter's symbolic character and performance. This is just one of the many social functions that design can perform in the foreseeable future, such as facilitating helping humanities and social sciences (HSS) to visualise data obtained through research.

Design is a cultural manifestation too, but what sort of culture does it stand for?

"KING LEAR:

$O$, reason not the need: our basest beggars

Are in the poorest thing superfluous:

Allow not nature more than nature needs,

Man's life's as cheap as beast's: thou art a lady;

If only to go warm were gorgeous,

Why, nature needs not what thou gorgeous wear'st,

Which scarcely keeps thee warm."

[William Shakespeare's King Lear]

Hence, superfluous things are also a need, even a basic need to be able to live: ancient wisdom said as much. Now we know that formal styles adopted to satisfy this need for ornaments and 
superfluous things just for embellishment's sake are decided culturally and socially. Personal taste is thus a sociological signal of social identity, whether this means the identity of a social class or an urban tribe. Another active hypothesis here is the one that assesses that the sort of aesthetic dimension which is effective and worthy within different design practices is revealed through the design factor; it also works vice-versa and defines the nature of the design factor itself. That is the reason why it is widely acknowledged that design itself is an aesthetic practice. Though sharing with arts this aesthetic dimension and aspiration, design performs its aesthetic and aestheticist role outside and apart from the world of the arts, that is, the universe of extraordinary things, remaining instead in an ordinary, more immediate and closer context but maintaining a constant dialogue with the arts (no matter whether they are popular art forms coming from urban suburbs or the avantgarde experiments developed within cosmopolitan high culture everywhere). Design becomes a symbolic form too and so it behaves symbolically. It has been finally accepted and so, recently, public politicians have provided an interesting summary of the whole question: "[Design is] an aesthetic and symbolic practice that is economically profitable and culturally relevant" [Working paper towards an EU innovation policy, 2008]. All these attributes are equally interesting to think about.

Among designers, it is quite easy to find talks asserting the cultural depth of design if done properly and well. It is worth pointing some of them out here. The first one comes from a BEDA White Book published some years ago that tries to summarise how design evolved at the beginning of the 21 st century, showing the socially pertinent issues that usually engage professional designers. For them, design practice clearly belongs to the cultural domain because "Design is capable of defining values, beliefs and attitudes. The design action on the rebound turns products and brands into culture and cultural forms." This was a statement made some time ago by Jordi Montaña, a professor of design management in Barcelona). Design action can thus turn culturally relevant proposals into economically beneficial performances. This is just one way. There are many others outside branding that perform a similar role. Since the early 1960s, Pop Art and Pop design widely demonstrated that statements such as the one above are right. Trademarks supplied evocative icons throughout the 20th century; mass-manufactured products and visual communications populating the artificial world transformed everyday environment into a landscape that could be appreciated aesthetically, whether it looked picturesque or photogenic. Then came advertising posters, road signs and signals, lettering signs and bags for shops moving around, all of them drawing the urban landscape just as much as architecture does. Visual communications might work as visual poems rather than just 'punching' the walking people's eyes from city walls and banners hung on streetlights. A long time ago, A.M. Cassandre, a poster and type designer working in France, asserted that art had finally gone down onto the street. Is this still the case? In his time, the early 1930s, the profusion of billboards displayed the aesthetic dimension of life while communicating, selling or just informing people about life's pleasures and practical needs.

Almost one hundred years later, the social function of well-designed products is even higher: "In other words, everything now depends on design" [due to] "its role as a bridge between technology and art, ideas and ends, culture and commerce is now important" (Macdonald 2004). A need for interesting and appealing everyday aesthetics is still in the air everywhere: is it felt as necessary? And is the need to improve it as necessary and urgent as it was at the turn of the 20th 
century or even earlier, when the social mission of design was clearly discussed? Design-driven behaviours are now quite normal and design practice takes an active role in different areas of life and managing practices, both privately and politically. But design values have disappeared a little bit behind the normalisation of its discourse and the many equally valuable and interesting trends available. Design can carry out its social mission in different ways: using an interesting and relevant one or an uninteresting, trivial and banal one. It depends on the designers and working conditions. Current life and values offer a good frame for experimenting with and developing many possibilities. The challenge is becoming even more complex because of the many aestheticisation processes going on and the central role aesthetic matters play in present economy. Indeed, managers are already fully aware of that:

The impossibility of finding explanations that encompass the complex, changing and at times erratic reality of society means that people live in the present, they tend to enjoy life, appreciate games and leisure activities, look for the things that will bring out extreme emotions and enjoy aesthetics. Design has to take cultural roots into account and transmit them, as that is what consumers want. Users and consumers demand something more that just functions, they ask for values. (Montaña 2004) ${ }^{8}$

This is thus the other side of the whole question: the aesthetic dimension of everyday tools and goods is also a consequence of merchandising and marketing practices, performed to increase sales and boost commercial reputation. Many and diverse aesthetic categories have been adopted by trade technicians in the last decades to announce and speak about consumer goods populating the global marketplace. The current aestheticisation of everyday life is also a consequence of this 'Instrumentalist Reason' that philosophers portrayed as the driving force of the era, but now suiting commercial interests more than the productive ones. In fact, the aesthetic appearance of things and the categories to describe them, whether the cosiness, cuteness or coolness of popular things, or the stylish and pretentious elegance of some allegedly luxury goods, are now commercial resources that can be easily identified and managed both for consumers and sellers. In short, the wide spread of aesthetics throughout everyday life everywhere, in both landscapes and behaviours, i.e. moving outside the world of art that characterises today's wealthy societies, all drive design and creative industries to take centre stage.

8. See Jordi Montaña: "Design As Cultural Carrier". See also Stuart Macdonald: "Introduction. Design Defines The Century" in Stuart Macdonald (ed.) 2004, (ed.) 2004 Design Issues in Europe Today, BEDA privately printed, pp.36, 37 and 6 respectively. 
Figure 3. View of the bridge built in Barcelona to cross the old port on foot and reach some facilities. Designed by the architects Helio Piñón and Albert Viaplana. Inaugurated in 1994. Barcelona. Photographed by the author.

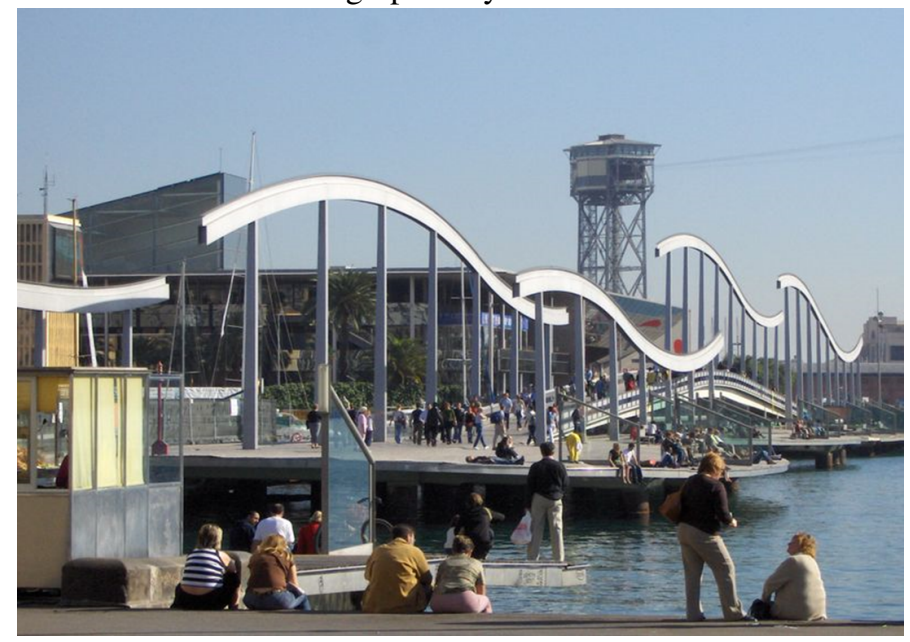

\section{Vindicating the sensory world and everyday pleasures; searching for motives behind an old hatred}

The theory of the aestheticisation of mature and financial capitalism raises many questions for scholars and people involved in design practice, design philosophy and design history. Some examples. Why is aestheticisation still a dismissive criticism for so many thinkers and philosophers reflecting on present times? Why are the more negative and pejorative meanings of aesthetics, aestheticism and aestheticist attitudes so often chosen when speaking about the aesthetic dimension of common life? Why have the dismissive, despising and disdaining meanings been so easily and widely accepted among design scholars and people working in design culture? And finally, and this is perhaps the most relevant question for our purposes, if focusing only on the negative effects of aestheticisation performances such as those complained about by Walter Benjamin regarding fascist parades, where is design's old utopia and legitimising discourse of being a culturally relevant aesthetic practice?

As already said, design can be seen as both a complex discipline, with a rich and varied culture of its own, and a difficult, technical and highly professionalised activity practised all around the world since modernisation processes began. In this context, how can design still be a culturally relevant human practice when working on interfaces and improving the appearance of screens? And, finally, is it still true that professional design is an aesthetic practice in the strong sense of the word aesthetic? If they are aesthetically competent, can designers' old skills still be helpful for them when working with technological new realities, whether hyper-modern, augmented or virtual? 
Design is usually considered a creative industry that was barely involved in the aestheticisation of everyday life throughout all of the $20^{\text {th }}$ century. Design is under suspicion since sociologists, philosophers and mass-culture analysts have deplored the aestheticisation undergone by whatever art or cultural performance was around at the time, drawing the process as one of banalisation. It is an important argument because it grieves and regrets the inner process of artistic and aesthetic creations itself much more than the fact that it can take economic advantage of its creations. We can consider this approach a legacy of postmodern thinking, although the bulk of criticism against the customisation of cultural goods comes from High Modern Philosophy, which usually blamed industrial production and its need to 'massify' everything to ready it for consumption: after the Second World War, this was the case for Adorno, Haug, Heidegger, Marcuse, most French structuralist thinkers (even Bourdieu) and Hannah Arendt among many others. The aim of the closing section is to inquire about the negative spirit usually felt when faced with aestheticisation processes that are still going on, and to observe how many scholars there are who argue against the aesthetic improvement of everyday life, including design work, of course! Given that literature on the issue is now very extensive, the main task will be a dialogue with the latest book by Gilles Lipovetsky and Jean Serroy, L'esthétisation du monde (Paris 2013). Its cover depicts a town full of awful skyscrapers around a false lake built in the middle of a desert; therefore a nightmarish movie waiting for us just around the corner.

Such criticisms are especially harsh and negative when, culturally speaking, aesthetic improvements affect the majority of the population. The question inspiring my thought here comes from personal astonishment. I feel really disappointed when the issue of the socialisation of culture, that is, the democratisation of true beauty and other cultural products, is used just to explain and justify the banalisation and impoverishment of the symbolic meanings of cultural products: metaphorically speaking, a decaffeinating action. This is something that has always existed but has never been as explicit as it is nowadays. A widespread idea states that "Le plaisir esthétique semble incompatible avec les contraintes du collectif" ["Aesthetic pleasure seems to be incompatible with the constraints of the collective"]. For sociologists, the main hindrances lie with necessary "dispositifs de facilitation des accès" ["access facilitation devices"] (Fabiani 2007: p.225). It must be accepted that this is a historical issue because it is based on the structure of social classes. Even Lipovestsky and Sarroy accept its aristocratic background (2013, pp.16-19), just as former and foundational authors, such as Werner Sombart and Thornstein Veblen, showed a long time ago. They were right. Women were accepted at the Court for the first time early in the Ancien Régime. Their arrival required male aristocrats, who were mostly members of the military, to refine their habits, tastes and manners. For this higher social class, life just meant leisure, entertainment and gallantry. Aesthetically enjoying all kinds of objects was a job in itself: In the end, the beautiful no longer concerned usefulness by definition. However, two centuries have now passed during which democracy and social mobility have been central values for society (regardless of whether or not mobility could really happen) except for aesthetic issues. After so long producing appealing and interesting products - even, or especially, for mass culture - it is actually difficult to unreservedly accept ideas based on such aristocratism. I prefer another view of the social role that design has been playing in our societies, one that the history of design demonstrates. As my friend Martín de Azúa, an important Spanish designer, once said: the task of design has long been to fight against 
banality, and very intensively too; at least it has done so insomuch as it has been helping the trade and commercialisation of goods to develop and spread capitalism everywhere. But even in these cases, design has sometimes helped change several dangerous and damaging habits to provide healthier, easier and more comfortable ways to perform everyday life's most common acts.

Let us return to Arendt once again. In 1959, in an article already quoted [2014: p. 41], she portrayed the situation from the social or sociological perspective, displaying all the nuances that the game between social classes entails and how they have evolved over history. Mass society itself is a socialisation phenomenon of culture. This is obvious, she states, and mass culture is essentially similar to the sort of culture that spread from intellectual 'salons' held by a high society, which was not yet massive but was totally exclusive. She was writing when mass culture started to spread massively. Much later, while thinking about the many transformations that went on in high culture affairs in France during the postmodern years, Jean Louis Fabiani, a French sociologist, recalled that the aim to socialise high culture is what most guided cultural policies in his country. ${ }^{9}$ This fact hides at least how difficult it still is to acknowledge cultural values outside the already institutionalised fine arts domain, and the persisting survival of a single hierarchy of cultural production. So to be included in the public policy for cultural affairs, it is better to become a work of art or a new form of art, and that is what design has strategically been done so many times. However, Arendt showed that difficulties between social classes regarding culture are not so deep: on the one hand, former high society behaved like the current masses do at present within mass society and so similar traits identified them as cultured people; on the other hand, if we look at actual numbers, the first representatives of a mass society were so few that they actually were and acted as a sort of elite. From my point of view, this is the secret and hidden paradox, the fundamental lie, underlying the current luxury industry; it also stirred Art Deco's style and manners, polite behaviours, during the interwar years and later. Sports, tourist trips by cruise or luxury train, weekend aperitifs: these are the topics of Cassandre's best posters. In the 1920s, a class of 'moderns', trendy and fashionable people lived an expensive lifestyle that however was similar to mass society afterwards. Among the shared traits that Arendt lists, there is one that draws much attention nowadays, a time so deeply marked by consumerism: "the extraordinary capacity (rather greed) for consumption, along with the inability to judge the qualities or simply identify them" (2014: p.41). To agree with her vision, it is useful to recall the laws against luxury that were approved all across Europe starting in the 16th century. Afterwards, she continues trying to understand what happened during the process that gave birth to what she calls "cultural philistinism" (2014: p.42). Here she uses a word of ancient lineage in Protestant Northern Europe, very familiar to 19th century intellectuals in Britain and Germany, who used it regularly when arguing against industry (as Ruskin did) or the capitalist society (like Morris). Her argument points towards entertainment but also social emulation through culture and good taste. This is just a sociological explanation, not an aesthetic one, because aesthetics and good taste are taken as playing a social and sociological function. In fact, "philistines" are those industrious members of the bourgeoisie obliged to spend their whole lives working just to earn their richness.

9. Jean Louis Fabiani (2007) Après la culture légitime. Objets, publics, autorités, Paris, L'Harmattan. The book is devoted to the "processus de déhiérarchisassions des corpus qui a marqué la vie culturelle du dernier quart de siècle" (1975-2000) (p.16). 
Once they became rich, philistines used their aesthetic competence and good taste, particularly those of their daughters, to separate people into classes, to mark differences clearly, and finally to caricature newly rich men, the actual philistines, these unfortunate "parvenus", always arriving in a very embarrassing and improper mood. They were and still are usually despised as "cursis", i.e. morally 'kitsch', a flashy or posh type. Arendt calls these characters "educated philistines" or "snobs". It must be remembered that, as Fabiani stated regarding today's audiences of culture: "la culture bourgeoise d'une époque ne se réduit jamais à sa culture savant" ["bourgeois culture of one era can never be reduced to its high culture"] and so, "...les cultures savantes ne constituent pas les cultures dominantes des élites" ["...high cultures are never the dominant cultures of the elite"] (Fabiani 2007: p.215). Certainly, aesthetic categories are well suited to labelling existing differences between behaviours and personalities, sometimes better than identifying forms, styles and formal appearances.

Impoverishment and banalisation, however, follow other shifts. According to Arendt, these negative processes arrive when cultural values spread and are shared by many people. They circulate but become another kind of value, an economic or social one: culture then adopts a social function to perform and so it avoids its transcendent want, desire and scope. Why? Simply because widely spread aesthetic values and cultural ideas are not extraordinary anymore; they do not serve to forget mundane matters, to move far away from the ordinary conditions of everybody's everyday lives. The ghost of exclusiveness is there again. Given that Arendt thinks that beauty, or the specific value that gives a product cultural relevance, is the will to endure, then mass culture, which produces cultural items industrially as a commodity to be consumed quickly and greedily ('devoured' Arendt says), cannot aim to be culturally valuable. If pleasant entertainment, although a biological need for people and a demand imposed by life itself, even when it is authentic, spontaneous or innocent, is proposed as a commodity; it thus cannot aspire to be culturally valuable (p.43): this is mass culture's original sin.

Although it might appear a bit pedantic, I would like to recall Kierkegaard's puritan condemnation of whatever innocent and immediate pleasures everyday life naturally offers. He gives the name of "aesthetic stadium" to the earliest and most elementary stage in a person's development of self. Indeed, a person able to aesthetically enjoy the world where he/she lives still has a long way to go before he/she achieves his/her personal realisation, the religious stage. Though at a very low level, at least Kierkegaard acknowledges that aesthetic enjoyment and nurturing the specific faculty of enjoying beauty and nice things results in a human being's progress into the humanity of a human being. The idea recalls what Montaigne stated some centuries before, in a very optimistic mood: aesthetic joy and competence is "what makes a human being humane". Moreover, a long time has passed since aesthetic enjoyment first came under suspicion and plenty of examples can be found in the history of philosophy. A very recent example is Lipovetsky \& Serroy book mentioned above. Their point of view further strengthens the "aristocratic" understanding of both the aesthetic dimension and whatever canons of beauty can be established. In fact, aristocracy gives its name to a chapter in the book and to a moment in art and aesthetic histories:

Plus l'art s'infiltre dans le quotidien et l'économie, moins il est chargé de haute valeur spirituelle; plus la dimension esthétique se généralise, plus elle apparaît comme un 
simple occupation de la vie, un accessoire n'ayant d'autre finalité que celle d'animer, décorer, sensualiser la vie ordinaire: le triomphe du futile et du superflu. [2013: p. 33]

[The more art infiltrates the everyday and the economy, the less it is responsible for high spiritual value; the more the aesthetic dimension spreads, the more it appears to be a simple pastime, an accessory with no other end than to enliven, to decorate, to make ordinary life more sensual: the triumph of the futile and the superfluous.]

In a way of thinking such as this, the aesthetic dimension and aestheticism itself mean in effect something void, superficial and simple, which is also quite sad. The idea of design has acquired similar connotations in recent times. In any case, the way of thinking about everyday pleasures and joys that despises the enjoyment of senses and sensations that small things in life so often provide are at the heart of the fine arts system and hierarchies of cultural manifestations and aesthetic practices. Design's aesthetic understanding needs to reverse this deeply rooted belief and find alternatives. In fact, the image of the two platonic aesthetic characters, Venus and Diotima, come again into play.

It may be useful to stop for a moment at another transitional time in aesthetic history, the first years of the postmodernist period. In 1972, the Catalan philosopher Xavier Rubert de Ventós wrote a book inquiring about cultural change from the aesthetic point of view. ${ }^{10}$ His aim was to integrate alternative cultural forms to update aesthetic and art theory so he also talked about design and mass media; TV was the main and most despised media at that time among left wing thinkers. His argument has two parts. The first one deals with the way a cultural expression becomes a cultural work, or rather a form of art, and is socially and intellectually acknowledged as such. Among several examples, two relate clearly to this field of inquiry: he draws attention to the fact that "design invented the painting as a bearer of eternal values" as much as "the invention of the plastic material has turned into art objects things made of wood or even tin" (1972: p.35).

Rubert's second line of reasoning aims to overcome contempt for everyday pleasures by showing how deeply rooted a hint of deep Puritanism that shapes current cultural values is in modern philosophy (1972: p.25-26). Faced with the ideas of Susan Sontag (1970s) and Ortega y Gasset (1930s), both of whom wanted to surmount "the hedonism of popular and easier forms of art", the 1970s saw "a spontaneous claim of the sweetish demonstrations of Symbolist art". British Pre-Raphaelites, French Pompier painters, symbolisms in Fine Arts, the New Liberty for decorative arts, and Victorian textiles too, such as those recovered by Laura Ashley, and multiple varieties of kitsch, all burst onto the art scene and into high cultured discourse with a lot of energy ( Сamp for instance, shaped the ambience of the period, and everything that reminds people of the atmosphere at a grandmother's house as well). Along the same lines, Rubert also remembers Peter Brook's vindication of "melodrama" and the melodramatic tone ("este espacio literario de la hipérbole emocional" ["this literary space of emotional hyperbole"]) and proposes it as the most suitable genre "in a secularised world" such as our own. Is this surrendering or rather a way to avoid Adorno's disdain for mass culture products, even the best Jazz music? Adorno's approach was incredibly elitist at the end, as Hans R. Jauss so clearly said when trying to get back

10. Xavier Rubert de Ventós (1972). See, in particular, part I, chapters 3-6. 
the pleasures of reading and recover enjoyment (many authors quoted here have stated something similar). ${ }^{11}$

Rubert uses similar examples to show how difficult it is to observe and realise what is actually going on at present - whatever historical time the present one refers to - and he grasps it using well established theories. He then reminds us that many other thinkers' aesthetic thought despises everyday pleasures and joys because they look far too simple and are just a spontaneous reaction. Arguing this position, he shows how it is becoming a topic. Nelson Goodman, for instance, once warned against the trap of confusing aesthetic feelings with the sensory and pleasant sensation provided by a warm bath (1984). Rubert remembers the old "Platonic-Kantian" story distinguishing between artists and chefs - although today's chefs and the artistic cult of gastronomy may totally refute that argument (1972: p.29n; p.30-34 too). Sensuality still remains at the lowest rung of the ladder and therefore hedonism is a synonym for vacuity and frivolity, clearly a sin for whatever puritan approach to art and aesthetics may be taken (and the spirit of Kierkegaard comes to the stage again). Rubert then displays the three requirements that a puritan theory of aesthetics and cultural values must satisfy: "the aesthetic dignity of themes and objects that can be applied to art; the humanist condition of faculties exercised or raised by art; and the transcendent value of formal experiences that supports its meaning and validation." The modernist way of thinking about art is thus accurately portrayed (1972: p.29).

Now we can clearly see the basic point. If the true question concerning the nature of art and artistic expression is "when something can be considered art" - instead of asking "what is art?", i.e. avoiding the ontological form of questioning - then aesthetic inquiry must focus on searching for when and in what situations "an object, a gesture or a text acquire a meaningful value that transcends its mere functional and conventional existence" (Rubert 1972: 31). A design aesthetics inquiry must therefore focus on investigating when and in what conditions an object or image could be beautiful whilst being functional and conventional enough to be used and clearly understood by everybody. An interesting topic to reflect upon! At least now it has been accepted that sensual pleasures are culturally valuable.

Continuing with Arendt's work, some pages below, she warned of the emergence of a totally new social phenomenon: "After the First World War, a bizarre social structure emerged in which neither literary critics, nor historians nor social scientists are noticed. It can be described as an international "society of celebrities"" (Arendt 2014: 71). Almost thirty years later, Gilles Lipovestky mentioned the same fact in his research on fashion and other ephemeral behaviours characteristic of modern times (L'Empire de l'éphémère. La mode et son destin dans les sociétés modernes 1987). He drew attention to the professionalisation of aesthetic competence and judgement at the turn of $20^{\text {th }}$ century through the building up of the fashion system. Celebrities have been playing the role of top communication models and spreading new trends among population. Since then, launching aesthetic models and references of beauty are in some way the job of the people specialised in developing means of dissemination and spreading new trends. Designers have been a very active part in the system, managing the industry of aesthetic goods. They have been claiming acknowledgement of their ability to renew aesthetic trends and styles, demonstrating that they are

11. Fabiani tried to overcome the Frankfurt School way of thinking this issue because of its essential elitism (p.16). 
aesthetically competent and displaying a capacity to give value to aesthetically bizarre or innovative proposals. When the postmodernist period started, when the Italian Memphis Group arrived in journals and magazines all around the globalised design world (1981), designers adopted the celebrities' behaviour too and so a design star system grew, supported by media and culture managers. It was a management strategy that was useful to get and increase social visibility and a specific place in society. These are the social and economic foundations upon which the aestheticisation of the world and the everyday universes has been built.

\section{Design under suspicion: vindicating aestheticism and aestheticisation performances}

The aestheticisation of everyday life is a phenomenon that identifies the last phase of capitalism both economically and socially, the postmodern phase ending with the deep crisis that started in 2008 in Europe, but announced since 2000 from Brazil, Argentina and Chile. It is therefore a postmodernist issue. It started long time ago and was introduced for the first time by Guy Deborde's famous book on the society of spectacle (1967). In practice, aestheticisation means what Veronica Delvalle summarised in four processes that have already been accomplished:

Consumption of trademarks replaces consumption of consumer goods; the development of image values such as personal or business identities; exacerbation of voyeurism; and appropriating of new models of beauty which have a strong visual and aestheticised imprint. [Devalle 2009]

The last premise that is actually at stake in this article is: what does it really mean and what operation is meant by "strong aestheticised imprint"? According to most orthodox philosophers, this genre of beauty is rather negative because it is essentially trivial: features such as charm, nicety or pleasant cosiness of everyday landscape mean, for them, not the manifestation of wellbeing and "savoir faire" of the intrinsic value of things, but an obstacle to experiencing true aesthetic experiences that must be extraordinary by definition. We have already seen to what extent the nostalgia of pathos is causing contempt of that subtle and modest beauty that may be present in daily life as something normal. Another fact is brought about thanks to ICT and social networks: the centrality of private and individual universes in today's cultural manifestations and affairs and the spread of the sentence "I like it" as the only significant means of communication. Fabiani, among any others, mentions the effects of the conversion of technology into a consumer good on cultural products: "Today, the private space is the main place of cultural dating, through technical audio-visual devices" (2007: p.228). As the number of available pictures increases and they enter private and domestic spaces, they become something ordinary (Fabiani is an expert on cinema who studies how it has evolved as a cultural event over the last decades). Another recurrent example of artworks losing cultural meaning because they are heard everywhere and for too long are the musical pieces used by restaurants to balance noise or turn the atmosphere of a dreadfully narrow elevator into a cosy one.

These examples have been collected to show how often aesthetic thinking just looks at the decaffeination operations visible in cultural performances. It is obvious that processes such as a decaffeination of values do happen in our world, and quite often together with other things that 
impoverish culture. Many things that look very trendy are actually badly made; luxury goods are, aesthetically speaking, absolutely vulgar in style for being luxurious; new cities do not have style or a cultural identity related to local traditions; and urban suburbs, although highly up to date, are ugly and increasingly sad everywhere in the world (Lipovetsky \& Serroy 2013: p.34 gives many examples of these phenomena). But they are as sad as the things targeted at poor people used to be in the past. As Ettore Sottsass remarked once (1973), throughout history there have been two kinds of craft, a production for rich and powerful people who ask for true art - no matter if these art works look extravagant - and, on the other hand, a craft for workers: "for people who need tools just to work with, not to help them to live, craft was - and still is - something brief; this craft has always been brief, subdued, melancholic, pathetic and sometimes even poignant." 12

Over more than 400 pages, as the old philosophical essays used to be in the past, Gilles Lipovetsky and Jean Serroy undertake their inquiry into the nature of the phase of capitalism they call artistic. The title clearly announces the approach: "L'esthétisation du monde: vivre à l'age du capitalisme artiste" ["The aestheticisation of the world: living in the age of artistic capitalism"]. It thus seems to be a kind of final stage. Planned as a survey on postmodern society, the book includes a historical review of cultural production and consumption throughout the 20th century and some former antecedents to discover how the processes of 'artialisation' took place. These processes led the world to acquire an aesthetic dimension. As their approach is conceptually so French, the authors think that every aesthetic display must be artistic and can only be seen and analysed as a form of art. For that reason, artialisation and aestheticisation are quite synonymous words for them. Their model of reference is cinema, whilst exchanges between high/low cultures focus on expressions of popular art such as jazz and pop music. These are the art forms that French sociology of culture has recently treated the most in the discussion of the legitimate culture issue. But both cinema and music are performing arts, providing fictional narratives or stories whether they use old or new technical means of expression. An aesthetics thought as suiting the art discourse fits perfectly in these cases.

Another modern founder of typical 20th century manners are Haute Couture and the fashion industry, a topic liked and raised by Lipovetsky himself. In these fields, the aesthetic discourse changes because fashion has been an industry and a trade since its birth. It therefore requires proper categories. It is worth remarking here that the authors devote several quite long chapters to industrial design, analysing its history and present condition - indeed, the book could be regarded as a work of design history with a sociological approach. Design is understood as an activity of making commercial goods and trading them as well. It becomes a suitable disclosure of "commercial aesthetics", a new dominion of aesthetics particular to postmodern times. Another chapter introduces a "world of design". The limits of their understanding of the design phenomenon are found in from the conceptualisation of design itself. Although they review its whole standard history, design is only considered in the perspective of art and therefore it appears to have the original sin of being a functional, ordinary, democratic and instrumental activity. It can seldom seek a true

12. 1973 Ettore Sottsass interviewed in Jordi Mañà: El diseño industrial, Barcelona, Salvat, pp.17-19 
aesthetic dimension and so it has to remain among the pleasant and pretty levels of simple culture and life. Design therefore still remains under suspicion. ${ }^{13}$

Some more words on the aristocratic and puritan background of the orthodox idea of aesthetics based on art and artistic practices. It is representative of the early modern period in art history, and so it was inherited by 20th century cultural isms. In that case, the democratisation of aesthetic values and practices, that is, their wide spread across society, ethnographic cultures and geographic places, is what actually causes their final demise. The authors state that plainly: "The more the aesthetic dimension spreads, the more it appears to be a simple pastime, an accessory with no other end than to amuse, to decorate, to make ordinary life more sensual: the triumph of the futile and the superfluous" (2013: pp.33-34). The main challenge for design and other aesthetic practices involved in creative industries is now openly launched. But are decoration, sensualisation and the superfluous the only purposes that everyday aesthetics can look to and aim for? To reach those purposes, when and why could it be a bad thing? There is a trap that must be absolutely avoided if we are aiming to develop an aesthetic thinking adapted and suited to design.

The question to raise is quite the opposite: the true job is to realise and discover the depth of meaning that common and modest things actually have just because they are pretty, friendly and kind. Indeed, a discreet and quiet beauty is also important and it helps make life better. There are no reasons for things to be ugly, corny tacky or banal; the subjectivity of personal tastes is no longer a reason. This is what 18th century philosophers already knew and tried to explain while understanding themselves and their common and simple tastes too. Another challenge arises now. It is worth remembering that modern aesthetics and early fine arts aware of their autonomy, when they were born during the 18th century, tried to overcome the canons of beauty so well established at that time and replace them with a search for the sublime. It was through sublime works that art connected with everlasting meanings and could transfigure to become an artwork. In contrast, beauty, this nearby beauty to be discovered in gardens instead of wild nature, in hills instead of mountains, in woods instead of the jungle, looked like something close, domestic, attainable, even habitable. It must be acknowledged that comfort has never been an epic or virile value, which are among the aesthetic categories best rated by arts, whether painting, opera, literature or videogames, even when involving the artialisation of cruelty and violence of men towards other men. On the other hand, many languages use the word "effeminate" to dismiss artworks whatever their style. French moralists of the $17^{\text {th }}$ century used this category to warn against terrible dangers that the arrival of women to the Court could bring about, causing a loss of military values. The rejection of all the comfortable and pleasant situations common life provides, rejecting even the possibility of enriching them by human design and making skills, therefore reveals a nostalgia for aristocratic culture and a lost world which is easy to find embedded in many apologies for the humanities. It is an approach that often hinders the understanding of present times. It is based on the premise that cultural practices and aesthetic decisions must always be for the sake of culture or arts. Here is an example:

13. "Et les esthétiques marchandes n'ont nullement l'ambition de nous faire toucher un absolu en rupture avec la vie quotidienne (...) C'est une esthétique de consommation et de divertissement dont il s'agit" (Lipovetsky \& Serroy 2013: 33). 'Comme il est rigolo!' a French student once said to me, to explain that they liked a piece of design that was nicely made but very cruel in spirit and meaning. 
Trans-aesthetic society has nothing sacred or noble in it; it is just another step in the progress of the merchant and democratic age which, by deregulating class culture, leads to the individualisation of taste along with an aesthetic ethics of consumption. [Ibid.]

However, some nostalgia for a better common life does also appear along the book. Their aesthetic model is quite similar to that of British 18th century more idealist philosophers such as Georges Berkeley. Lipovetsky and Sarroy, in their introductory statements, display their own ideal of everyday pleasures. It is in fact a picture of that "slow culture" that is so fashionable now, or the image of a simple life that $19^{\text {th }}$ century British thinkers liked to remember. Indeed, they do not discuss the present aestheticisation:

...in the name of an ascetic aesthetic revisited but on behalf of a higher aesthetic ideal that intends to serve the wealth of individual existence, an ideal which favours sensations of the self and the world. Refocusing on the internal time and emotions of the moment, the unexpected availability and the lived moment, enjoying beauties at hand, the luxury of slowness and contemplation. [Ibid.]

This is a truly simple aesthetic life. Recently, a Catalan thinker opened another path to work with. Speaking about home and its reassuring meanings for people, he valued private and domestic experiences, stating a highly suggestive argument: "To experience home not only as a shelter against the cold weather, but as a refuge where one feels protected against the frosty ambiance of metaphysics" (Esquirol 2013: p.12). They are just words, but he is also right.

Current aesthetics-specific issues are the topic of the last chapters of Lipovetsky and Sarroy's book. Their central theme is the 'trans-aesthetics' dynamic. At the beginning, this current, or rather postmodernist, trans-aesthetics is presented as a way of consuming, simply a set of consumer preferences. Afterwards, they emphasise several new dichotomies portraying an aesthetic reasoning that actually moves people within their social, cultural and physical environment. The book is decidedly too long to be treated in detail here. There are however some interesting theses to mention. The first one is the essential paradox based upon which present economy and social behaviour takes place. The aestheticisation of the world displays the success and the failure of highly developed capitalism: "We always consume more beauties, but our life is not more beautiful" (2013: pp.32, 33). Therein the authors are totally right. The 'real world' so praised by designer Victor Papanek (1971) is full of ugly and distasteful, nasty things; they are even more nasty and shoddy than they were in William Morris' time. So, for the authors, beauty can no longer save the world. But this is exactly the opposite thesis of the one that Italian designers Sottsass and Mendini, worldwide gurus of postmodern design, have been stating. They favour a hope in design because "only beauty can save us" and "underlying design there is always "la utopia della bellezza". ${ }^{14}$ But now, the difficulty, and the most exciting challenge, depends on the fact that

14. Ettore Sottsass: "Si algo nos salvará, será la belleza". Ettore Sottsass, obituari El País, 3.01.2008; Alessandro Mendini's speech at the homage he received at adi fad during the event Mestres de la Cadena del FAD, Barcelona 14.12.15: I have attempted to develop this issue of the utopia embedded in beauty in an article to be publish by the ThRAD on-line magazine in an issue on utopia and design. 
"Il n'y a pas un seul model d'esthétique..." ["There is not a single model of aesthetics..."] (2013: p.35).

This is the main issue at stake at present. Are there true differences between the ways of behaving, making, enjoying and living from an aesthetic point of view? Are they meaningful? They might be, insofar as extreme individualisation could impose it because everyone has to reinvent him/herself. If there are differences, then design aesthetics makes sense to study and appreciate those differences and note how many varied levels of quality are inherent to each.

\section{It is time to conclude. What might 'culturally relevant' mean for aesthetics at present?}

Design aesthetics is finally being acknowledged as a specific field of inquiry. It has significantly grown in recent decades. We can conclude that it is what postmodernism left as its legacy to the $21^{\text {st }}$ century and the new era starting afterwards. As said, for research, a notable area is the demise of all aesthetic canons, whether for beauty or ugliness or other aesthetic categories (corny, tawdry, nasty, cute, cool, trendy, tacky, yokel and so on). There is no longer a high culture model accepted just because it expresses the dominion of a social class through aesthetic competence and education. Talking in current French terms, postmodernism brought about the fall of legitimate cultures and the likelihood of no more undeniable reference models or "legitimate culture models". In consequence, the present challenge for current design aesthetic thinking is to decide when and how aesthetic proposals can be culturally relevant because they are not and can no longer be a renewed expression of ancient, modern or eternal examples. As many design historians have been trying to elude since the 1950s, after the Pop approach to cultural history, the axiological notion of culturally relevant itself has been censured because it looks like an imposition of art history, a concept imported without being adapted to the real and specific nature of design activity and culture.

Judging design qualities and grasping the design factor's cultural relevance needs to go beyond the comparison with the early-avant-garde artistic proposals that are so explicit in some design pieces. Pop historians contested the idea that the social role of design is to bridge high culture and mass consumption and to play a pedagogical role through which the mass public becomes familiar with the best art. Outside the art world, how could cultural relevance be understood? As already seen, academic philosophy and social sciences find it hard to approach common and ordinary aesthetic behaviour. Turning to Arendt's thought again, her understanding of cultural relevance is strongly connected with fine arts' nature because it is a value for explaining things in terms of everlasting power. There are some things able to outlive the people who made them and remain in existence a long time after their maker's imagination could plan. It is a sort of transcendence, the effect of a transfiguration that certain pieces of art achieve. There should be an attempt for the focus not to fall too much on the side of educated culture, whether high culture or traditionally legitimate culture. So, as happened to Pierre Bourdieu, Gilles Lipovetsky and Jean Sarroy's sociological schemes, Arendt too approaches popular culture from a rather classist schema. However, she opens the door to design and many other current creative activities (such as videogames, for example, which have so epic and virile narratives) to aspire to the status of artwork without having to become decorative art. We should also examine the thoughts taking 
aesthetic enjoyment as the outcome of a humanly refined and developed human faculty. I have already mentioned Montaigne from the late Renaissance period, and some philosophers of the Enlightenment time as well; Plato's dialogues could also help. In the $20^{\text {th }}$ century, however, Arendt reinforced this view by drawing attention to how often aesthetic taste is active when living and moving around:

It's just a matter of taste, which never ceases to judge things of the world, to set limits and provide a human meaning to the realm of the culture. Or rather, something which means the same: its function is to make culture not barbarianism (...). Taste is the faculty through which culture humanises. [2014: p. 63]

The ghost of Jean Jacques Rousseau is also present in the background. Slavoj Žižek remembered Rousseau recently too. His "amour de soi" announced current self-hedonism. For Žižek, it reveals the sort of subjectivity that has formed modern times' ideology and mentality since Hegel gave them their former shape. A little bit later, Žižek remarks that processes of humanisation such as these ones are rather complex and require a lot of time and effort. For that reason they are involved in a word such as 'civilising' (Žižek 2014: p.149). ${ }^{15}$

These points of view do a great deal to accept the prosaic and humble pleasures provided by everyday life to a lot of people; it also helps to regain the old schema of modern aesthetics focused on former beauty, even if plain, neighbouring and restful, and to leave sublime and transcendent experiences just for the exceptional moments offered by arts experienced in the right places. Whether the expression of polished tradition over a long time, or revealing the latest interesting novelties, there is a profound truth in common and nearby objects of use and communication. This is so because, as Žižek remarked while talking about the beauty of handsome women, "there is more truth in appearance than what is hidden behind it" (2015: p. 82). What does everyday life hide that can be relevant to philosophical aesthetics? What kind of truth are we talking about? Another philosopher already quoted, Josep M. Esquirol, brings us an interesting portrait of everyday life and its possible aesthetic crannies. He wrote about a way of living quite similar to "slow" culture:

In daily work that is undertaken to earn a living, there is also the satisfaction of needs. Several daily acts are not mediations and are satisfied just for their own sake. Every day is consequently a path (it has a sense of direction) but also a meaning (a sense already present in life). To live enjoying life: delight in the world of food and drink, sex and entertainment.

Enjoying is therefore the way in which needs are satisfied: "and with this enjoyment, the symposium, the banquet, the joy shared can happen." We could say then that, he concludes, "there is a sense of life tied to the everyday." Human features do not need a higher, transcendent area to reveal themselves. They already do, and with the same strength, in everyday gestures. The author devoted a previous chapter to domestic houses looking at all the senses that make a house a home (Chapter III, 'Back at home'): "Home is always a symbol of restful intimacy" (2015: p.38-39). Esquirol's reasoning reminds me of one of William Morris' assertions that encouraged

15. Slavoj Zizek (2014) Acontecimiento, Madrid-Méjico, Sexto piso, 2015/2a.p.149 
restfulness and calm as sensations worth designing for in things to put at home. Morris said that arguing against Ruskin's plea to employ fine painters as the only way to achieve aesthetic quality in home decoration. Morris refuted Ruskin, hinting to him that everyday life at home cannot support the deep and intense triggers that the contemplation of true and transcendent art demands. Strong emotions and experiences, intense games with sentiments and catharsis, all that must be experienced extraordinarily and have their own places to happen. In his praise of the everyday and its values of closeness, Esquirol goes ahead searching words that better describe the roots of the happiness of being at home: calm and restfulness are among these. They provide the physical and psychological conditions for rest:

...what prevails is the rest and shelter of privacy. Not so much comfort or luxury as withdrawing and welcoming. The house, both in its origin and as dreamt, is always a room not a construct, it is always a space, not walls. Rest and peace require protection; rest, to be rest, must be protected. The deep desire for peace explains the strength of a home (whether remembered, dreamed of or real) (...) The desire for protected privacy has roots that are so extensive, they escape us. In the basement, something important is revealed about the meaning of life. [2015: p.39]

What has provided a true and interesting aesthetic dimension to everyday things, even the useful and instrumental ones, to everybody everywhere and for so long ago? To explain it as simply as possible, three major roles of aesthetics in everyday life are widely accepted and proved. The aesthetic dimension of things works by displaying human beings' expression of: people's joy of living; people's pleasure in self-embellishment and the delights of games and playing, the 'ludic' experiences in short. All these aspects together mark the field of activity of the design factor, its duties and mission, as far as it does express them in designed objects. On the other hand, as said before, the performance of these roles involves a rating of quality and so they swing between the worst moral sin (to drink until drunk) and the most pleasant and delicate enjoyment (to drink a tasty wine or beer): Bernard de Mandeville said that for the first time at the turn of $18^{\text {th }}$ century (The Fable of the Bees, 1714). To enjoy products obtained following a lot of science, effort, care, attention and cultivation demands a lot of civilisation to be accomplished. Therein lies the true cultural challenge and the utopia that the ancient concept of beauty entailed. In that way, designs can aspire to be part of and play a role in the inner dialogue human beings maintain to live. Two challenges now appear clearly outlined on the horizon: recovering the cultural value of everyday things to make the world ecologically sustainable and, on the other hand, designing with people instead of designing for people. Both are exciting challenges and could be inspiring requirements for designers in the near future.

Anna Calvera

\section{References}

Arendt, H. (2014). Más allá de la filosofía. Escritos sobre cultura, arte y literature (Fina Birulés \& Ángela Lorena Fuster eds.), Madrid: Trotta. (first edition 2012); The Human Condition (1958) Chicago, University of Chicago Press (on-line open access). 
Badiou, A. (2005). Le siècle. Paris: Seuil.

Capdevila, C. (2015). Entendre el món amb onze pensadors contemporanis (H. Arendt; Z. Bauman; S. Benhabib; J. Butler; A. Heller; J. Gray; J. Rifkin; S. Sassen; R. Sennett; G. Steiner; A. Touraine \& T. Todorov). Barcelona: Arcàdia.

Devalle, V. (2009). La travesía de la forma. Buenos Aires: Paidós.

Esquirol, J. M. (2015). La resistència íntima: assaig d'una filosofia de la proximitat. Barcelona: Quaderns Crema.

Fabiani, J. L. (2007). Après la culture légitime. Objets, publics, autorités. Paris: L'Harmattan.

Goodman, N. (1984/1 $\left.{ }^{\text {st }}\right)$. De la mente y otras materias. Madrid: Visor1995.

Hennion, A. (2005). Pour une pragmatique du goût. Papiers de Recherche du CSI - CSI Working Papers Series, (1). Paris: Centre de Sociologie de l'Innovation. Available on-line open access.

Mandoki, K. (2006). Estética cotidiana y juegos de la cultura. Prosaica I; Prácticas Estéticas e identidades sociales. Prosaica II. México: Siglo XXI editores [English translation by Ashgate, available on Google Chrome]

McDonald, S. (coord.) (2004). Temas del diseño en la Europa de hoy. BEDA: Brussels. www.bcd. es/site/unitFiles/1795/lbiro_beda.pdf

Rubert de Ventós, X. (1972). La estética y sus herejías. Barcelona: Anagrama.

Viladàs, X. (2008). Diseño rentable (pp. 161-162). Barcelona: Index Book.

Povedano, R. (2005). La batedora de braç. Doctoral Dissertation, Anthropology Department, Universitat Rovira i Virgili, Tarragona.

Zizek, S. (2014). Acontecimiento. Madrid-Méjico: Sexto piso, 2a. 